\title{
KEWENANGAN PENGELOLAAN SUMBER DAYA ALAM PADA ERA OTONOMI KHUSUS DI ACEH
}

\author{
Efendi \\ Fakultas Hukum Universitas Syiah Kuala \\ Email: fendie_idris@yahoo.co.id
}

\begin{abstract}
At the time of the enactment of Act No. 18 of 2001, there is no specific authority granted to Aceh in natural resource management. Everything related to the management of natural resources in Aceh, authorities still follow the general provisions. So the authority in natural resource management is no different with other provinces in Indonesia. But with the enactment of Act No. 11 of 2006 be another condition, because through tis Act Aceh was given huge authority in managing natural resources which include mining consisting of mineral, coal, geothermal, forestry, agriculture, fisheries, and marine good that exist on land or in the ocean.
\end{abstract}

Keyword: Authority, Natural Resources, Special Autonomy

\begin{abstract}
Abstrak
Pada masa berlakunya Undang-Undang Nomor 18 Tahun 2001, tidak ada kewenangan khusus yang diberikan kepada Aceh dalam pengelolaan sumberdaya alam. Segala yang berkaitan dengan pengelolaan sumberdaya alam di Aceh, kewenangannya tetap mengikuti ketentuan yang terdapat dalam peraturan perundang-undangan pada umunya. Sehingga kewenangan dalam pengelolaan sumberdaya alam tidak ada perbedaan dengan provinsi-provinsi lainnya yang ada di Indonesia. Tetapi dengan lahirnya UndangUndang Nomor 11 Tahun 2006 kondisinya menjadi lain, karena Aceh diberikan kewenangan yang begitu luas dalam mengelola sumberdaya alam yaitu meliputi pertambangan yang terdiri atas pertambangan mineral, batu bara, panas bumi, bidang kehutanan, pertanian, perikanan, dan kelautan baik yang ada di daratan maupun yang ada di lautan.
\end{abstract}

Kata kunci: Kewenangan, sumberdaya alam, otonomi khusus

\section{A. Pendahuluan}

Kehidupan manusia sangat tergantung pada sumberdaya alam. Sumberdaya alam merupakan modal utama dan fundamental untuk memenuhi kebutuhan kehidupan umat manusia. Berkaitan dengan hal tersebut, maka optimalisasi penggunaan sumberdaya alam harus dicapai dengan mempertimbangkan aspek potensi, kesesuaian, kelestarian dan konsistensi manfaat untuk mewujudkan keberlanjutannya (Muh Aris Marfai, 2005: 94). Untuk mencapai optimalisasi ini diperlukan adanya tindakan pemeliharaan pada titik keseimbangan yang normal. Di sini sumberdaya alam memiliki peran sebagai modal pertumbuhan ekonomi (resource based economy) dan sekaligus sebagai penopang sistem kehidupan (life support system). oleh karena itu sumberdaya alam senantiasa harus dikelola secara seimbang untuk menjamin keberlanjutan pembangunan nasional, dan untuk sebesarbesarnya kemakmuran rakyat (Hafrijal Syandri,

108 Yustisia Vol. 3 No.2 Mei - Agustus 2014
2007: 1) Atas dasar ini, maka sumberdaya alam merupakan modal penting dalam menggerakkan roda pembangunan dan menjadi isu strategis dalam pelaksanaan pembangunan baik dalam kontek pembangunan negara, propinsi maupun kabupaten/kota.

Menurut Undang-Undang Nomor 32 Tahun 2004 tentang Pemerintahan Daerah, kewenangan pendayagunaan sumberdaya alam strategis berada pada pemerintah pusat, tetapi daerah juga mempunyai wewenang untuk mengelola sumberdaya alam yang ada di wilayahnya. Sehingga dapat dikatakan, pengelolaan sumberdaya alam dalam kontek otonomi daerah ini pada dasarnya adalah power sharing kewenangan pengelolaan sumberdaya alam antara pemerintah dengan provinsi dan kabupaten/kota (Hikmat Ramdan, 2003: 11). Untuk menghindari penyalahgunaan kekuasaan sebagai akibat meningkatnya wewenang pemerintahan daerah dari adanya power sharing dimaksud, diperlukan penyamaan persepsi dari semua 
pihak dalam menterjemahkan otonomi daerah. Karena jika tidak maka akan berpotensi timbulnya pemahaman tentang otonomi daerah yang keliru. Pemahaman otonomi daerah yang keliru ini akan menimbulkan beberapa permasalahan. Adapun beberapa permasalahan tersebut antara lain:

1. Timbulnya daerah miskin dan kaya, hal ini terjadi dikarenakan penyebaran sumberdaya alam di Indonesia yang tidak merata. Sehingga secara nasional menimbulkan ketimpangan kesejahteraan;

2. Konflik pemanfaatan sumberdaya lintas kabupaten/kota. Hal ini dapat terjadi terhadap sumberdaya alam yang keberadaannya meliputi beberapa wilayah kabupaten/kota. Misalnya sumberdaya hutan dan mineral yang terdapat dalam satu hamparan yang berbatasan antar kabupaten;

3. Konflik pemanfaatan sumberdaya open access (laut), misalnya nelayan yang berasal dari suatu kabupaten/kota tidak boleh menangkap ikan yang berada pada wilayah perairan kabupaten/kota yang lain;

4. Pengurasan sumberdaya alam secara besarbesaran oleh daerah bagi kepentingan dana pembangunan;

5. Potensi sumberdaya manusia yang rendah, sehingga berpengaruh pada produktivitas, efektivitas, dan efisiensi dalam pemanfaatan sumberdaya alam (Hikmat Ramdan dkk, 2003: 11).

Dari adanya permasalahan dalam pelaksanaan otonomi daerah dalam pengelolaan sumberdaya alam sebagai akibat dari adanya pemahaman yang keliru tentang otonomi daerah sebagaimana disebutkan di atas, maka diperlukan kesiapan dari masing-masing tingkatan pemerintahan dalam menyikapi pelaksanaan otonomi daerah, terutama yang berkaitan dengan kebijakan pengaturan bidang sumberdaya alam di daerah. Jika hal ini tidak dilakukan, maka berpotensi timbulnya penyalahgunaan kekuasaan sebagai akibat meningkatnya wewenang pemerintahan dari adanya power sharing dimaksud. Apalagi jika suatu daerah seperti Provinsi Aceh yang berstatus status otonomi khusus, yang memiliki kewenangan lebih dibandingkan dengan provinsi lain, maka potensi penyalahgunaan yang demikian akan lebih mungkin terjadi.

Berkaitan dengan beberapa hal di atas, maka penulis disini melakukan kajian tentang berbagai kewenangan dan permasalahan dalam pengelolaan sumberdaya alam di Provinsi Aceh. Adapun permasalahan yang dikaji tersebut meliputi bagaimana kewenangan pengaturan sumberdaya alam pada era otonomi di daerah pada umumnya? dan bagaimana pula kewenangan pengelolaan sumberdaya alam di Aceh yang berstatus sebagai daerah otonomi khusus?

\section{B. Kewenangan Pengelolaan Sumberdaya Alam Pada Era Otonomi di daerah}

Implementasi desentralisasi di Indonesia amat beragam, dan seolah-olah tidak konsisten satu sama lain, sehingga berpengaruh pada kemanfaatan asas desentralisasi itu sendiri. Padahal dengan desentralisasi memberikan peluang untuk memandirikan daerah dalam mengatur dirinya sendiri. oleh sebab itu, masalah desentralisasi yang paling penting adalah adanya kemauan politik dari pemerintah yang menyerahkan kewenangannya kepada daerah otonom (Siswanto Sunarso, 2008: 123).

Kebijakan otonomi daerah bidang sumberdaya alam, merupakan pilihan politik yang diharapkan mampu menjaga keberlanjutan dan kelestarian sumberdaya alam. Sistem pemerintahan yang sentralistik sebelumnya terbukti telah menghancurkan sumberdaya alam. Sebab secara ekonomi-politik sistem pemerintahan sentralistik terbukti membawa kecendrungan buruk berupa (1) politik yang tidak demokratis, (2) korupsi, (3) rent-seeking activities yang memperburuk social welfare loss bagi masyarakat, dan (4) moral hazart (Tridoyo Kusumastanto, 2003: 66). Padahal dalam pelaksanaan otonomi daerah keberadaan sumberdaya alam di daerah memegang peranan yang sangat penting, hal ini dikarenakan sumberdaya alam merupakan faktor yang memberikan pengaruh terhadap kemampuan dan pertumbuhan serta pengembangan suatu daerah. Apabila sumberdaya alam yang ada di daerah tersebut dapat dikelola dan dimanfaatkan dengan baik, maka pelaksanaan otonomi yang luas, nyata dan bertanggungjawab dapat terlaksanakan dengan baik dan sesuai dengan delegasi wewenang yang telah di berikan kepada daerah. otonomi yang luas di sini diartikan sebagai keleluasaan daerah untuk menyelenggarakan pemerintahan yang mencakup kewenangan semua bidang pemerintahan, kecuali kewenangan di bidang politik luar negeri, pertahanan keamanan, peradilan, moneter dan fiskal, agama serta kewenangan bidang lainnya yang ditetapkan dengan peraturan pemerintah (Enny Nurbaningsih, 2011: 585). Selanjutnya makna otonomi nyata, diartikan keleluasaan daerah untuk menyelenggarakan kewenangan pemerintahan di bidang tertentu yang secara nyata ada dan diperlukan serta tumbuh, hidup 
dan berkembang di daerah. Sedangkan istilah otonomi yang bertanggungjawab diartikan sebagai perwujudan pertanggungjawaban sebagai konsekuensi pemberian hak dan kewenangan kepada daerah dalam mencapai tujuan pemberian otonomi, berupa peningkatan pelayanan dan kesejahteraan masyarakat yang semakin baik, pengembangan kehidupan demokrasi, keadilan, dan pemerataan, serta pemeliharaan hubungan yang serasi antara pusat dan daerah serta antara daerah dalam rangka menjaga keutuhan Negara Republik Indonesia.

Menurut Agussalim Andi Gadjong (2011: 164), pelaksanaan otonomi yang luas, nyata dan bertanggungjawab di atas mencerminkan semangat radical change dalam 5 (lima) pikiran dasar yaitu:

1. Sebagai upaya mewujudkan otonomi daerah dengan memberikan keleluasaan kepada daerah untuk menjadikan daerah otonom yang mandiri;

2. Penyelenggaraan otonomi yang luas di atas prinsip-prinsip demokrasi, pemerataan dan keadilan serta memperhatikan potensi dan keanekaragaman daerah;

3. Meningkatkan fungsi dan peran Dewan Perwakilan Rakyat Daerah (DPRD) sebagai badan legislatif daerah dan badan pengawas sebagai saranan pengembangan demokrasi serta medudukkan kesejajaran dan kemitraan antar kepala daerah dan DPRD dalam menyelenggarakan pemerintahan daerah;

4. Untuk mengantisipasi perkembangan keadaan, baik di dalam negeri maupun tantangan persaigan global yang pengaruhnya akan melanda daerah;

5. Untuk mendudukkan kembali posisi desa sebagai kesatuan masyarakat hukum terendah yang memiliki hak asal usul dan otonomi asli yang diakui dan dihormati dalam sistem pemerintahan Negara Kesatuan Republik Indonesia (NKRI).

Pelaksanaan kewenangan dalam otonomi yang luas, nyata dan bertanggungjawab yang didelegasikan kepada daerah, bisa meliputi kewenangan zelfwetgeving dan zelfbestuur, yang mengakomodir kepentingan rakyat dalam penyelenggaraan pemerintahan secara demokratis. Namun, hakekatnya suatu negara kesatuan, pendelegasian kewenangan tidak bermakna lepas dari campur tangan dan kontrol pemerintah pusat, karena legal standing pemerintah daerah dalam hal ini bersifat "subordinate" terhadap pemerintah pusat. Daerah selalu dituntut membangun hubungan yang harmonis dengan pusat, dan apabila bertindak diluar kontrol pusat maka dapat mengancam keutuhan "nationstate" (Agussalim Andi Gadjong 2011: 164).

Adanya delegasi wewenang dari pemerintah pusat kepada daerah memberikan konsekuensi perlunya pelaksanaan pembangunan di daerah harus lebih professional dan mandiri. Artinya pemerintah daerah dituntut untuk melaksanakan fungsi-fungsi manajemen yang lebih komprehensif, yaitu adanya keterkaitan proses antara perencanaan, pelaksanaan dan evaluasi kegiatan pembangunan daerah yang berkesinambungan (Robert J. Kodoatie dkk, 2002: 4). Konsekuensi lain dari pelaksanaan otonomi daerah adalah menghormati dan mewujudkan aspirasi, kebutuhan dan gagasan rakyat dalam menyelesaikan permasalahan yang timbul.

Pelaksanaan otonomi daerah telah membawa banyak perubahan, baik ditingkat pusat maupun ditingkat provinsi dan kabupaten/kota. Perubahan tersebut diantaranya menyangkut dengan pengelolaan sumberdaya alam. otonomi daerah dalam pengelolaan sumberdaya alam ini pada dasarnya bertujuan untuk memberikan keleluasaan kepada daerah dalam mengelola dan memanfaatkan sumberdaya alam bagi kesejahteraan masyarakat di daerah. Dalam pelaksanaan pengelolaan sumberdaya alam di daerah dalam kenyataannya terlihat terkotak-kotak dalam wilayah adimistratif. Padahal daya dukung sumberdaya alam di setiap administratif tidak sepenuhnya mampu mendukung pembangunan dan kehidupan jangka panjang, sehingga diperlukan kerjasama antar daerah untuk mencapai kesejahteraan bersama dan keberlanjutan sistem penyangga kehidupan. Bagitu juga pendekatan pengelolaan sumberdaya alam sektoral (seperti pertambangan, kehutanan dan perikanan) dapat menimbulkan perebutan sumberdaya alam dan tumpang tindihnya kebijakan diantara sektor-sektor tersebut (Yanis Rinaldi, 2009: 73). Bahkan dapat menimbulkan konflik hukum berupa pertentangan peraturan perundangundangan secara hirarkhis. Oleh karena itu untuk melaksanakan fungsi-fungsi pemerintahan sebagai konsekuensi dari pelaksanaan otonomi daerah bidang sumberdaya alam ini, diperlukan adanya pemerintahan yang memenuhi kriteria good governance. Menurut Bambang Yudoyono, (2001, hlm. 4-5) pemerintahan yang memenuhi kriteria good governance adalah:

1. Pilihan dan penunjukan pejabatnya yang berkompeten;

2. Menerapkan prinsip transparansi dalam melaksanakan aspek dan fungsi pemerintahan di daerah; 
3. Melakukan akuntabilitas secara yuridis terhadap setiap tindakan dan keputusannya kepada publik;

4. Mampu mendorong partisipasi masyarakat dalam menjalankan pemerintahan;

5. Harus memiliki kepastian dan penegakan hukum (rule of law) yang jelas;

6. Menjunjung prinsip kesetaraan dan keadilan bagi seluruh rakyat.

Dengan demikian wujud good governance adalah penyelenggaraan pemerintahan yang solid, bertanggungjawab serta efisien dan efektif dengan menjaga sinergi interaksi yang konstruktif diantara domain-domain negara, dan masyarakat. oleh karena good govenance meliputi sistem administrasi negara, maka upaya mewujudkannya juga merupakan upaya menyempurnakan administrasi negara yang berlaku pada suatu negara secara menyeluruh (Jazim Hamidi dan Mustafa Lutfi, 2010 : 158).

otonomi daerah bidang sumberdaya alam merupakan pelimpahan wewenang dalam penyelengagaraan pemerintahan pengelolaan sumberdaya alam. otonomi daerah dalam pengelolaan sumberdaya alam ini sifatnya adalah terpadu. Artinya pemerintahan daerah dalam menyelenggarakan urusan sumberdaya alam haruslah berkoordinasi dengan pemerintah dan pemerintahan daerah lainnya. Keterpaduan ini terlihat dari isi yang dikandung oleh Pasal 2 angka 4, 5 dan 6, Undang-Undang Nomor 22 Tahun 1999, yang mengatakan pemerintahan daerah dalam menyelenggarakan urusan sumberdaya alam pemerintahan memiliki hubungan dengan Pemerintah dan dengan pemerintahan daerah lainnya.

Selanjutnya keterpaduan yang berkaitan dengan penyelengaraan pemerintahan bidang urusan sumberdaya alam juga terdapat dalam 7 Undang-Undang Nomor 32 Tahun 2004. yang mengatakan:

(1) Hubungan dalam bidang pemanfaatan sumber daya alam dan sumber daya lainnya antara pemerintah dan pemerintahan daerah sebagaimana dimaksud dalam Pasal 2 ayat (4) dan ayat (5) meliputi:

a. Kewenangan, tanggung jawab, pemanfaatan, pemeliharaan, pengendalian dampak, budidaya, dan pelestarian;

b. Bagi hasil atas pemanfaatan sumber daya alam dan sumberdaya lainnya; dan

c. Penyerasian lingkungan dari tata ruang serta rehabilitasi lahan.
(2) Hubungan dalam bidang pemanfaatan sumber daya alam dan sumber daya lainnya antar pemerintahan daerah sebagaimana dimaksud dalam Pasa1 2 ayat (4) dan ayat (5) meliputi:

a. pelaksanaan pemanfaatan sumber daya alam dan sumber daya lainnya yang menjadi kewenangan daerah;

b. kerja sama dan bagi hasil atas pemanfaatan sumber daya alam dan sumber daya lainnya antar pemerintahan daerah; dan

c. pengelolaan perizinan bersama dalam pemanfaatan sumber daya alam dan sumber daya lainnya.

(3) Hubungan dalam bidang pemanfaatan sumber daya alam dan sumber daya lainnya sebagaimana dimaksud pada ayat (1) dan ayat (2) diatur dalam peraturan perundangundangan.

Menindaklanjuti kewenangan yang berkaitan dengan pengelolaan sumberdaya alam, pemerintah mengeluarkan peraturan pemerintah Nomor 38 Tahun 2007 tentang Pembagian Urusan Pemerintahan Antara pemerintah, Pemerintahan Daerah Provinsi dan Pemerintahan Daerah Kabupaten/Kota. Dalam Lampiran Peraturan Pemerintah Nomor 38 Tahun 2007 ini, secara rinci disebutkan tentang sektor sumber daya alam yang menjadi kewenangan masing-masing tingkatan pemerintahan dalam pengelolaannya.

Berkaitan dengan berbagai kewenangan bidang sumberdaya alam yang diberikan oleh berbagai peraturan perundang-undangan kaitannya dengan otonomi daerah, menurut Muh Aris Marfai (2005: 34-37), ada beberapa hal yang perlu mendapat perhatian dalam pengelolaan sumberdaya alam:

1. Keberadaan potensi sumberdaya alam di setiap daerah terdistribusi tidak merata secara nasional, berlainan dan sangat beragam. Pada beberapa daerah potensi dan kekayaan sumberdaya alam melimpah, sedangkan pada beberapa daerah lainnya potensi tersebut sangat kecil. Hal ini akan menimbulkan ketimpangan dan kesenjangan yang sangat besar, dimana daerah yang mempunyai sumberdaya alam melimpah akan berkembang semakin kaya, sedangkan daerah yang mempunyai potensi sumberdaya alam yang kuranag menjadi lebih terbelakang;

2. Perspektif pengelolaan dan pemanfaatan sumberdaya alam adalah ekosistem, sedangkan otonomi daerah adalah berdasarkan unit administratif. Berdasarkan 
pada kenyataan ini, bahwa pengelolaan dan pemanfaatan sumberdaya alam dalam rangka otonomi daerah tidak bisa lepas dari keberadaan daerah-daerah di sekitarnya, sehingga wewenang pengelolaan yang dimiliki oleh daerah yang bersangkutan tidak merupakan otoritas penuh, melainkan harus ada frame work bersama dengan beberapa daerah yang secara ekosistem terpengaruh. oleh karena perlunya mekanisme kerjasama dan perangkat infrastruktur yang mengatur dan menangani pengelolaan dan pemanfaatan sumberdaya alam antara berbagai daerah yang berkaitan dengan ekosistem dimana sumberdaya alam tersebut berada.

3. Paradigma indikasi kemajuan pembangunan masih bertumpu hanya pada peningkatan secara ekonomis dan non ekologis, serta indikasi kemajuan daerah hanya pada pendapatan asli daerah (PAD), akibatnya kemungkinan pemanfaatan sumberdaya alam yang berwawasan lingkungan akan terabaikan. Apabila paradigma ini tidak diubah, maka kesempatan eksploitasi sumberdaya alam akan berpindah dari pusat ke daerah, dari kapitalis nasional ke kapitalis lokal. Padahal substansi dari otonomi daerah memberikan kewenangan kepada daerah untuk mengelola sumberdaya alam dan dimanfaatkan sebesar-besarnya untuk kesejahteraan masyarakat di daerah dengan tetap menjaga kelestariannya.

4. Kesiapan sumberdaya manusia di daerah dalam melakukan pengelolaan sumberdaya alam perlu mendapat perhatian yang serius. Hal ini penting karena ketidakmampuan dan kesalahan yang dilakukan oleh pengelola (perangkat sumberdaya manusia) dalam pengelolaan sumberdaya alam akan membawa pada kemiskinan ekologis dan degradasi lingkungan yang lebih parah.

Pentingnya memberikan perhatian yang serius terhadap pengelolaan sumberdaya alam sebagaimana disebutkan di atas, dikarenakan Indonesia merupakan negara yang memiliki kekayaan yang melimpah. Misalnya hutan tropis yang dimiliki oleh bangsa Indonesia mencapai luas 139 juta hektar, sumberdaya ikan mencapai 6,7 juta ton per tahun. Bahkan yang tidak kurang banyaknya berupa hasil-hasil tambang, baik berupa minyak bumi, gas bumi dan berbagai bahan mineral lainnya (Hikmat Ramdan dkk, 2003: 5). Oleh karena itu potensi sumberdaya alam yang begitu besar ini diperlukan pengelolaan yang bijaksana, guna memberikan manfaat yang sebesar-besarnya bagi kemakmuran rakyat
Indonesia, sebagaimana diamanatkan oleh pasal 33 Undang-Undang Dasar 1945 dengan tidak melupakan kelestarian dari sumberdaya alam itu sendiri. Artinya sumberdaya alam tersebut tetap mempunyai fungsi kelestarian dengan tetap tersedia bagi generasi yang akan datang, dan tidak menghilangkan kegunaan bagi generasi sekarang.

Di Indonesia pemanfaatan sumberdaya alam secara bijaksana ini belum terealisasi dengan baik, hal ini terlihat dari arah pengelolaan selama ini, yang hanya dinikmati oleh sebahagian orang saja dan belum diperuntukkan bagi sebesar-besarnya kemakmuran rakyat sebagaimana diamanatkan oleh Pasal 33 ayat (3) Undang-Undang Dasar 1945, yang menyatakan "Bumi, air dan kekayaan alam yang terkadung di dalamnya dikuasai oleh negara dan diperuntukkan sebesar-besarnya bagi kemakmuran rakyat". oleh karena itu untuk mewujudkan pengelolaan sumberdaya alam secara bijaksana, menurut owen (Dalam Hikmat Ramdan dkk, 2003: 15), haruslah dilaksanakan berdasarkan prinsip-prinsip:

1. Tanggungjawab pribadi; tanggungjawab seorang warga negara yang demokratis ditandai dengan rasa tanggungjawab dalam menjalankan kewajiban terhadap pemerintah, sesama manusia dan sumberdaya alam;

2. Peranan pemerintah; pemerintah sebagai regulator dalam pengelolaan sumberdaya alam mempunyai peranan yang sangat penting. oleh karena itu pemerintah harus mampu menciptakan suatu sistem yang dapat menjamin pemanfaatan sumberdaya alam secara tepat;

3. Penggunaan ganda suatu sumberdaya alam; ketersediaan sumberdaya alam pada umumnya terbatas, untuk meningkatkan manfaat dan menghindari konflik kepentingan, sedapat mungkin sumberdaya alam dipergunakan secara ganda;

4. Inventarisasi dan proyeksi penggunaan sumberdaya alam; Inventasrisasi yang menyeluruh dan proyeksi penggunaan sumberdaya alam dapat memperkirakan tingkat kecukupan sumberdaya alam dan tindakan-tindakan yang perlu dilakukan untuk menjamin ketersediaannya;

5. Hubungan pertauatan antar sumberdaya alam; Antara sumberdaya alam yang satu dengan sumberdaya alam lainnya terjalin suatu keterkaitan, perubahan yang terjadi pada suatu sumberdaya alam akan menyebabkan perubahan terhadap sumberdaya alam yang lainnya.

Selain itu menurut Riyadi, (Dalam Hikmat Ramdan dkk, 2003:16-17) upaya pemanfaatan 
sumberdaya alam yang bijaksana juga dapat dilakukan dengan memperhatikan hal-hal sebagai berikut:

1. Perlunya legal frame work dan Law enforcement baik pada tingkat nasional maupun regional yang mampu mewadahi pemanfaatan sumberdaya alam secara lintas daerah dalam kerangka terpadu secara nasional yang akan mengurangi konflik antar daerah;

2. Perlunya legal frame work dan Law enforcement baik pada tingkat nasional maupun regional yang mendukung upaya pemanfaatan sumberdaya alam secara berkelanjutan dan ramah lingkungan, sehingga mampu mengurangi distorsi pengelolaaan ekonomis terhadap keberlanjutan ekosistem yang sehat dan berimbang;

3. Perlunya peningkatan keterlibatan aktif segenap unsur yang mewakili masyarakat dalam melakukan pengawasan dan pengendalian pemanfaatan sumberdaya alam;

4. Perlunya upaya percepatan pengembangan wilayah yang utuh dan terpadu sesuai dengan potensi lokal bagi daerah yang tidak memiliki sumberdaya alam strategis dan vital.

\section{Pengelolaan Sumberdaya Alam Pada Era Otonomi Khusus di Aceh}

Undang-Undang Nomor 18 Tahun 2001 memberikan kewenangan yang bersifat khusus kepada Provinsi Aceh. Dalam Pasal 3 UndangUndang Nomor 18 Tahun 2001 disebutkan bahwa kewenangan Provinsi Aceh adalah kewenangan dalam rangka pelaksanaan otonomi khusus. Adanya kewenangan ini tidak menafikkan kewenangan yang sudah diperoleh Aceh berdasarkan peraturan perundang-undangan lainnya, terutama kewenangan yang diperoleh berdasarkan Undang-Undang Nomor 44 Tahun 1999 yang meliputi bidang agama, adat, pendidikan dan peran ulama dalam pembuatan kebijakan.

Berdasarkan penjelasan umum, hal mendasar yang diatur dalam Undang-Undang Nomor 18 Tahun 2001 ini adalah pemberian kesempatan yang lebih luas untuk mengatur dan mengurus rumah tangga sendiri termasuk sumbersumber ekonomi, menggali dan memberdayakan sumber daya alam dan sumber daya manusia, menumbuhkembangkan prakarsa, kreativitas dan demokrasi, meningkatkan peran serta masyarakat, menggali dan mengimplementasikan tata bermasyarakat yang sesuai dengan nilai luhur kehidupan masyarakat Aceh, memfungsikan secara optimal Dewan Perwakilan Rakyat Daerah Provinsi NAD dalam memajukan penyelenggaraan pemerintahan di Provinsi NAD dan mengaplikasikan syariat Islam dalam kehidupan bermasyarakat.

Berdasarkan penjelasan Undang-Undang Nomor 18 Tahun 2001 sebagaimana disebutkan di atas, pada prinsipnya kewenangan yang bersifat khusus yang diberikan kepada Pemerintah Nanggroe Aceh Darussalam berbeda dengan kewenangan dari pemerintah daerah sebagaimana diatur dalam Undang-Undang Nomor 32 Tahun 2004. Pengertian khusus di sini pada umumnya merupakan penyelenggaraan secara khusus sesuai dengan karateristik dan kondisi daerah yang bersangkutan. Sehingga otonomi khusus bagi Aceh yang bertalian dengan pelaksanaan Syariat Islam, tidak berbeda dengan status Aceh sebagaimana diatur dalam Undang-Undang Nomor 44 Tahun 1999 (Bagir Manan, 2005: 16).

Meskipun pada bagian penjelasan umum Undanng-Undang Nomor 18 Tahun 2001 ada kalimat yang menyatakan "pemberian kesempatan yang lebih luas untuk mengatur dan mengurus rumah tangga sendiri termasuk sumber-sumber ekonomi, menggali dan memberdayakan sumber daya alam," tetapi dalam batang tubuh tidak ada norma khusus yang mengatur tentang kewenangan di bidang pengelolaan sumberdaya alam. Yang diatur hanya berkenaan dengan dana perimbangan bagian Provinsi Nanggroe Aceh Darussalam, kabupaten dan kota dari hasil sumberdaya alam. Adapun dana perimbangan dimaksud meliputi:

a. Bagi hasil dari sumberdaya alam yang ditetapkan sesuai dengan ketentuan peraturan perundang undangan, yaitu bagian dari penerimaan pajak bumi dan bangunan sebesar $90 \%$ (sembilan puluh persen), bea perolehan hak atas tanah dan bangunan sebesar $80 \%$ (delapan puluh persen), pajak penghasilan orang pribadi sebesar $20 \%$ (dua puluh persen), penerimaan sumber daya alam dari sektor kehutanan sebesar 80\% (delapan puluh persen), pertambangan umum sebesar $80 \%$ (delapan puluh persen), perikanan sebesar $80 \%$ (delapan puluh persen), pertambangan minyak bumi sebesar 15\% (lima belas persen), dan pertambangan gas alam sebesar 30\% (tiga puluh persen);

b. Dana alokasi umum yang ditetapkan sesuai dengan peraturan perundang-undangan; dan

c. Dana alokasi khusus yang ditetapkan sesuai dengan peraturan perundang-undangan dengan memberikan prioritas bagi Provinsi Nanggroe Aceh Darussalam. 
d. Penerimaan dalam rangka otonomi khusus, berupa tambahan penerimaan bagi Provinsi Nanggroe Aceh Darussalam dari hasil sumber daya alam di wilayah setelah dikurangi pajak, yaitu sebesar $55 \%$ (lima puluh lima persen) untuk pertambangan minyak bumi dan sebesar $40 \%$ (empat puluh persen) untuk pertambangan gas alam selama delapan tahun sejak berlakunya undang-undang ini. Mulai tahun kesembilan setelah berlakunya undang-undang Nomor 18 Tahun 2001 pemberian tambahan penerimaan dalam rangka otonomi khusus menjadi sebesar 35\% (tiga puluh lima persen) untuk pertambangan minyak bumi dan sebesar $20 \%$ (dua puluh persen) untuk pertambangan gas alam.

Selain dari yang disebutkan di atas, tidak ada satu pasalpun dalam batang tubuh yang mengatur tentang kewenangan di bidang sumberdaya alam. Sehingga dapat dikatakan Undang-Undang Nomor 18 Tahun 2001 tidak menyerahkan kewenanagn khusus dalam pengelolaan sumberdaya alam. oleh karena itu segala kewenangan yang berkaitan dengan pengelolaan sumberdaya alam tetap mengacu Pada Peraturan Pemerintah Nomor 25 Tahun 2000 tentang Kewenangan Pemerintah Dan Kewenangan Propinsi Sebagai Daerah otonom.

Pada masa berlakunya Undang-Undang Nomor 18 Tahun 2001, tidak adanya kewenangan khusus yang diberikan kepada Aceh dalam pengelolaan sumberdaya alam. Segala yang berkaitan dengan pengelolaan sumberdaya alam di Aceh, kewenangannya tetap mengikuti ketentuan yang terdapat dalam Peraturan Pemerintah Nomor 25 Tahun 2000. Sehingga kewenangan dalam pengelolaan sumberdaya alam tidak ada perbedaan dengan provinsiprovinsi lainnya yang ada di Indonesia.

Seiring dengan perjalanan waktu, UndangUndang Nomor 18 Tahun 2001 dirasakan belum cukup memadai untuk menampung aspirasi dan kepentingan pembangunan ekonomi dan keadilan politik di Aceh. oleh karena itu UndangUndang Nomor 18 Tahun 2001 diganti dengan Undang-Undang Nomor 11 Tahun 2006 tentang Pemerintahan Aceh. Lahirnya Undang-Undang Nomor 11 Tahun 2006 ini merupakan salah satu upaya untuk meretas hadirnya keadilan dan pencapaian tujuan otonomi khusus bagi Aceh dalam kerangka negara kesatuan Republik Indonesia, yaitu mencapai kesejahteraan secara demokratis di Aceh. (Husni Jalil, 2008: 127-128). Dalam menyelenggarakan otonomi khusus ini, masyarakat Aceh diberikan kesempatan untuk berperan serta dalam merumuskan, menetapkan, melaksanakan dan melakukan evaluasi terhadap kebijakan pemerintahan daerah. Wujud dari kebijakan daerah di sini adalah pengaturan kewenangan yang luas untuk mempercepat kesejahteraan yang berkeadilan dan keadilan yang berkejehteraan di Aceh (Andi Abidin, 2012: 291-292).

Undang-Undang Nomor 11 Tahun 2006, mendelegasi banyak hal dalam bidang pengelolaan sumberdaya alam dan lingkungan hidup untuk diatur dengan peraturan perundang-undangan daerah. Hal ini terlihat dari ketentuan Pasal 149 dan 150 Undang-Undang Nomor 11 Tahun 2006, yang memberikan kewajiban dan larangan kepada pemerintah, Pemerintah Aceh dan pemerintah kabupaten/kota untuk:

1. Melakukan pengelolaan lingkungan hidup secara terpadu dengan memperhatikan tata ruang, melindungi sumber daya alam hayati, sumber daya alam nonhayati, sumber daya buatan, konservasi sumber daya alam hayati dan ekosistemnya, cagar budaya, dan keanekaragaman hayati dengan memperhatikan hak-hak masyarakat adat dan untuk sebesar-besarnya bagi kesejahteraan penduduk;

2. Melindungi, menjaga, memelihara, dan melestarikan taman nasional dan kawasan lindung;

3. Mengelola kawasan lindung untuk melindungi keanekaragaman hayati dan ekologi;

4. Mengikutsertakan Lembaga Swadaya Masyarakat (LSM) yang memenuhi syarat dalam pengelolaan dan perlindungan lingkungan hidup;

5. Untuk melakukan pengelolaan kawasan ekosistem Leuser di wilayah Aceh dalam bentuk pelindungan, pengamanan, pelestarian, pemulihan fungsi kawasan dan pemanfaatan secara lestari.

6. Pemerintah, Pemerintah Aceh, dan pemerintah kabupaten/kota dilarang mengeluarkan izin pengusahaan hutan dalam kawasan ekosistem Leuser.

Selain larangan dan kewajiban dalam pengelolaan sumberdaya alam, kaitannya dengan pelaksanaan otonomi khusus bagi Aceh, juga diberikan kewenangan yang luas dalam pengelolaan sumberdaya alam dimaksud. Hal ini terlihat dari bunyi Pasal 156 ayat (1), (2), dan (3) Undang-Undang Nomor 11 Tahun 2006, yang menyatakan:

(1) Pemerintah Aceh dan pemerintah kabupaten/ kota mengelola sumber daya alam di Aceh 
baik di darat maupun di laut wilayah Aceh sesuai dengan kewenangannya;

(2) Pengelolaan sebagaimana dimaksud pada ayat (1) meliputi perencanaan, pelaksanaan, pemanfaatan dan pengawasan kegiatan usaha yang dapat berupa eksplorasi, eksploitasi, dan budidaya;

(3) Sumber daya alam sebagaimana dimaksud pada ayat (1) meliputi bidang pertambangan yang terdiri atas pertambangan mineral, batu bara, panas bumi, bidang kehutanan, pertanian, perikanan, dan kelautan yang dilaksanakan dengan menerapkan prinsip transparansi dan pembangunan berkelanjutan.

Berdasarkan ketentuan Pasal 156 Undang-Undang Nomor 11 Tahun 2006 di atas memperlihatkan, bahwa pemberian otonomi dalam pengelolaan sumberdaya alam kepada Pemerintahan Aceh begitu luas yaitu meliputi pertambangan yang terdiri atas pertambangan mineral, batu bara, panas bumi, bidang kehutanan, pertanian, perikanan, dan kelautan baik yang ada di daratan maupun yang ada di lautan.

Berkaitan dengan pengelolaan sumberdaya alam pertambangan mineral dan batu bara selain yang terdapat dalam Pasal 156 ini, tidak ada konkrititasi pengaturan baik dalam batang tubuh maupun dalam penjelasannya, kecuali pengaturan tentang dana pengembangan masyarakat yang diatur dalam Pasal 159 yang mengatakan:

(1) Setiap pelaku usaha pertambangan yang melakukan kegiatan usaha pertambangan di Aceh berkewajiban menyiapkan dana pengembangan masyarakat;

(2) Dana pengembangan masyarakat sebagaimana dimaksud pada ayat (1) ditetapkan berdasarkan kesepakatan antara pemerintah Aceh dan pemerintah kabupaten/ kota, dan pelaku usaha yang besarnya paling sedikit $1 \%$ (satu persen) dari harga total produksi yang dijual setiap tahun;

(3) Rencana penggunaan dana pengembangan masyarakat guna membiayai program yang disusun bersama dengan memperhatikan kebutuhan masyarakat sekitar kegiatan usaha dan masyarakat di tempat lain serta mengikutsertakan pelaku usaha yang bersangkutan diatur lebih lanjut dalam qanun Aceh;

(4) Pembiayaan program pengembangan masyarakat dengan dana pengembangan masyarakat sebagaimana dimaksud pada ayat (2) dan ayat (3) dikelola sendiri oleh pelaku usaha yang bersangkutan.
Tidak adanya kejelasan lebih lanjut dari berbagai kewenangan di bidang pertambangan mineral dan batu bara, dapat menimbulkan tafsiran yang luas terhadap kewenangan di bidang pertambangan ini. Sehingga disharmoni dengan peraturan perundang-undangan di atasnya sangat mungkin terjadi. Apalagi jika dilihat dari kacamata Peraturan Pemerintah Nomor 38 Tahun 2007 tentang Pembagian Urusan Pemerintahan Antara Pemerintah, Pemerintahan Daerah Provinsi, dan Pemerintahan Daerah Kabupaten/Kota, yang tidak memberlakukan peraturan pemerintah ini untuk provinsi Aceh sebagaimana disebutkan dalam Pasal 19 ayat (2) yang berbunyi "Urusan pemerintahan di Provinsi Papua dan Provinsi Nanggroe Aceh Darussalam berpedoman pada peraturan perundang-undangan yang mengatur otonomi khusus daerah yang bersangkutan."

Hal ini sangat berbeda dengan bidang pengelolaan sumber daya alam minyak dan gas bumi. Dalam Pasal 160 Undang-Undang Nomor 11 Tahun 2006 yang secara konkrit mengatur tentang kewenangan pengelolaan sumberdaya alam dimaksud, yaitu:

(1) Pemerintah dan Pemerintah Aceh melakukan pengelolaan bersama sumber daya alam minyak dan gas bumi yang berada di darat dan laut di wilayah kewenangan Aceh;

(2) Untuk melakukan pengelolaan sebagaimana dimaksud pada ayat (1), Pemerintah dan Pemerintah Aceh dapat menunjuk atau membentuk suatu badan pelaksana yang ditetapkan bersama;

(3) Kontrak kerja sama dengan pihak lain untuk melakukan eksplorasi dan eksploitasi dalam rangka pengelolaan minyak dan gas bumi dapat dilakukan jika keseluruhan isi perjanjian kontrak kerja sama telah disepakati bersama oleh Pemerintah dan Pemerintah Aceh;

(4) Sebelum melakukan pembicaraan dengan pemerintah mengenai kontrak kerja sama sebagaimana dimaksud pada ayat (3), Pemerintah Aceh harus mendapat persetujuan Dewan Perwakilan Rakyat Aceh (DPRA);

(5) Ketentuan lebih lanjut mengenai hal sebagaimana dimaksud pada ayat (1), ayat (2), danayat(3)diaturdengan PeraturanPemerintah.

Konkritisasi pengaturan tentang pengelolaan sumberdaya alam juga terlihat pada bidang perikanan dan kelautan yang terdapat dalam Pasal 162 Undang-Undang Nomor 11 tahun 2006 yang berbunyi:

(1) Pemerintah Aceh dan pemerintah kabupaten/ kota berwenang untuk mengelola sumberdaya alam yang hidup di laut wilayah Aceh. 
(2) Kewenangan untuk mengelola sumberdaya alam yang hidup di laut sebagaimana dimaksud pada ayat (1) meliputi:

a. Konservasi dan pengelolaan sumber daya alam di laut;

b. Pengaturan administrasi dan perizinan penangkapan dan/atau pembudidayaan ikan;

c. Pengaturan tata ruang wilayah laut, pesisir, dan pulau-pulau kecil;

d. penegakan hukum terhadap peraturan yang dikeluarkan atas wilayah laut yang menjadi kewenangannya;

e. Pemeliharaan hukum adat laut dan membantu keamanan laut; dan

f. Keikutsertaan dalam pemeliharaan kedaulatan Negara Kesatuan Republik Indonesia.

(3) Pemerintah Aceh dan pemerintah kabupaten/kota berwenang menerbitkan izin penangkapan ikan dan pengusahaan sumber daya alam laut lainnya di laut sekitar Aceh sesuai dengan kewenangannya.

(4) Pengelolaan sumber daya alam di wilayah laut sebagaimana dimaksud pada ayat (1), ayat (2), dan ayat (3) dilakukan dengan memperhatikan prinsip-prinsip pembangunan berkelanjutan dan pelestarian lingkungan hidup.

Berdasarkan ketentuan Pasal 156 ayat (3) Undang-Undang Nomor 11 Tahun 2006 sebagaiamana dijelaskan di atas, dapat dipahami bahwa pemerintah Aceh dan pemerintah kabupaten/kota berwenang untuk mengelola sumberdaya alam di Aceh, baik yang ada di darat maupun yang ada di laut. Hal ini bermakna bahwa, pemerintah Aceh dan pemerintah kabupaten/kota tidak hanya mempunyai hak atas sumberdaya alam, tertapi juga berkewajiban dan bertanggungjawab untuk mengelola sumberdaya alam dimaksud. Untuk itu dalam pengelolaannya dibutuhkan pengaturannya, yang oleh Irwandi Yusuf (Gubernur
Aceh periode 2007-2012) dikatakan pengaturan tersebut berada di tangan Pemerintah Aceh (Aceh Magazine, 2007: 13). Akibat dari adanya kewenangan khusus inilah menjadi salah satu penyebab timbulnya ketidakterpaduan pengaturan pengelolan sumberdaya alam dengan peraturan perundang-undangan di atasnya. Karena dalam setiap pembentukan qanun bidang sumberdaya alam disandarkan pada Undang-Undang Nomor 11 Tahun 2006 dimaksud. Persoalan lebih jauh adalah bagaimana dengan kewenangan yang tidak disebutkan secara konkret dalam Undang-Undang Nomor 11 Tahun 2006, sementara Peraturan Pemerintah Nomor 38 Tahun 2007 tidak berlaku bagi Provinsi Aceh, kemanakah kewenangan pembentukannya disandarkan? Konsekuensi dari kondisi ini, di Aceh terjadi kekosongan hukum (Eddy Purnama dkk, 2009: 48). Untuk menghindari terjadinya kekosongan hukum ini, maka seharusnya peraturan pemerintah yang khusus mengatur tentang kewenangan bidang sumberdaya alam segera dikeluarkan.

\section{Penutup}

Pada masa berlakunya Undang-Undang Nomor 18 Tahun 2001, tidak ada kewenangan khusus yang diberikan kepada Aceh dalam pengelolaan sumberdaya alam. Segala yang berkaitan dengan pengelolaan sumberdaya alam di Aceh, kewenangannya tetap mengikuti ketentuan yang ditetapkan dalam peraturan perundangundangan pada umumnya. Sehingga pengelolaan sumberdaya alam, dalam pelaksanaannya tidak ada perbedaan dengan provinsi-provinsi lainnya yang ada di Indonesia. Tetapi hal ini menjadi lain setelah berlakunya Undang-undang Nomor 11 Tahun 2006, karena Aceh memiliki kewenangan yang sangat luas dalam pengeloaaan sumberdaya alam yaitu meliputi pertambangan yang terdiri atas pertambangan mineral, batu bara, panas bumi, bidang kehutanan, pertanian, perikanan, dan kelautan baik yang ada di daratan maupun yang ada di lautan. 


\section{daftar Pustaka}

Agussalim Andi Gadjong. 2011. "Analisis Filosofis Pemerintahan Daerah Dalam Pergantian (perubahan) Kaidah Hukum Dasar Negara". Jurnal Hukum \& Pembangunan. Tahun Ke-41 Nomor 1 Januari. 2011. Jakarta: Fakultas Hukum Universitas Indonesia.

Andi Abidin. 2012. "otonomi Khusus Dalam Negara Kesatuan Menurut Sistem Ketatanegaraan Berdasarkan Undang-Undang Dasar Negara Republik Indonesia Tahun 1945”. Disertasi. Makasar: Program Doktor Ilmu Hukum Pascasarjana Universitas Muslim Indonesia.

Bagir Manan. 2005. Menyongsong Fajar Otonomi Daerah. Pusat Studi Hukum. Yogyakarta: Fakultas Hukum Universitas Islam Indonesia

Bambang Yudoyono. 2001. Otonomi Daerah, Desentralisasi dan Pengembangan SDM Aparatur Pemda dan Anggota DPRD. Jakarta: Pustaka Sinar Harapan.

Eddy Purnama dkk. 2009. “Identifikasi Qanun Aceh Dalam Upaya Menumbuhkan Iklim Usaha Menuju Demokrasi Ekonomi Berdasarkan Undang-Undang Dasar Tahun 1945”. Laporan Hasil Penelitian Sesuai Prioritas Nasional. Banda Aceh: Universitas Syiah Kuala.

Enny Nurbaningsih. 2011. “Implikasi Hierarki Baru Terhadap Sistem Legislasi Pusat dan Daerah”. Jurnal Legislasi Indonesia Vol. 8 No. 4 Desember 2011. Jakarta: Direktorat Jenderal Peraturan PerundangUndangan Kementerian Hukum dan Hak Asasi Manusia RI.

Hafrijal Syandri. 2007. Konservasi dan Rehabilitasi Sumberdaya Alam. Padang: Bung Hatta University Press.

Hikmat Ramdan dkk. 2003. Pengelolaan Sumberdaya Alam dan Otonomi Daerah: Perspektif Kebijakan dan Valuasi Ekonomi. Bandung : Alqaprint Jatinangor.

Husni Jalil. 2008. Hukum Pemerintahan Daerah. Banda Aceh: Syiah Kuala University Press.

Jazim Hamidi dan Mustafa Lutfi. 2010. Civic Education, Antara Realitas Politik dan Implementasi Hukumnya. Jakarta: Gramedia Pustaka Utama.

Muh Aris Marfai. 2005. Moralitas Lingkungan, Refleksi Kritis Atas Krisis Lingkungan Berkelanjutan. Yogyakarta: Wahana Hijau (WeHa).

Robert J. Kodoatie dkk. 2002. Pengelolaan Sumberdaya Air Dalam Otonomi Daerah. Yogyakarta: Andei.

Siswanto Sunarso. 2008. Hukum Pemerintahan Daerah di Indonesia. Jakarta: Sinar Grafika.

Tridoyo Kusumastanto. 2003. Ocean Policy Dalam membangun Negeri Bahari di Era Otonomi Daerah. Jakarta: Gramedia Pustaka Utama

Yanis Rinaldi. 2009. “Pengelolaan Lingkungan Hidup Dalam Era otonomi Daerah”. Laporan Hasil Penelitian Fundamental. Banda Aceh. Fakultas Hukum Unsyiah. 